\title{
Design and Development of Early Detection Protocol for Screening of Immune System
}

\section{Rajesh Laik*}

CFTRI - Mysore, Food Preneur, AFDSTI Life Member, Karnataka, India

*Corresponding Author: Rajesh Laik, CFTRI - Mysore, Food Preneur, AFDSTI Life

Member, Karnataka, India.
Received: March 02, 2020

Published: March 20, 2020

(C) All rights are reserved by Rajesh Laik.
Our health protocol is developed with our daily routine with natural way by common population and in planned system for particular individual whose lifestyle is comfortable, this type of screening depends on lifestyle management how we mange in our daily life and dinacharya, not every individual have their uniform lifestyle, so we need to choose ideal and standardize our lifestyle management for best health care. So, our immune system s always boosted up like we take natural vaccines in child hood care.

\section{Protocol thus follows}

- Food habit - to feedback the metabolism and its clock check

- Metabolic clock is key factor feedbacks the liver and Enzyme inhibition.

- Metabolic clock depend upon the Km/Vmax of Enzyme affinity for enzyme for food as medicine and check the free enzyme turnover.

- $\mathrm{Km} /$ Vmax Is key equation to balance the hormone and Enzyme, thus clock is regulated.

- Working system/nature of work

- Yoga system to make it habit.

Without proper food and planned dieting chart we cannot get oxygenated blood as yoga need oxygen to perform Bhastrika to Brahmri and udgeeth this pranayam check our respiratory system, there fore we need oxygenated blood. Thus we can perform our dinacharya in well planned manner with boost up immune system. Our hemoglobin count give the evidence in our daily work how many hrs we work/day/this counts our $\mathrm{Hb}$ and immunity T4 Cell.

Thus, Bio sense the CD8 MHC2 system and hence daily lifestyle and hormones. Regulation cell cycle and its repair mechanism de- pends upon this T4 Thymus cell which checks the aging and HIV viral infection with $\mathrm{Hb}$. surface protein membrane changes the ligand -receptor mechanism, lie drug delivery system. Complementary factor comes here to bind the foreign antigen.

\section{Conclusion}

Regulation of cell circuitry mechanism helps to satisfy the protocol and the clock behavior In the cell cycle, in immunity.

\section{Assets from publication with us}

- Prompt Acknowledgement after receiving the article

- Thorough Double blinded peer review

- Rapid Publication

- Issue of Publication Certificate

- High visibility of your Published work

Website: www.actascientific.com/

Submit Article: www.actascientific.com/submission.php Email us: editor@actascientific.com

Contact us: +919182824667 